\title{
Circulating Glucose-Regulated Protein 78 Levels in Patients with Chronic Hepatitis B Infection
}

\author{
Kronik Hepatit B Enfeksiyonlu Hastaların Dolașımında GRP78 Seviyesi
}

\author{
(1) Selma CIRRIK1, (1) Yeliz ÇETINKOL2, (1) Arzu ALTUNÇEKIÇ YILDIRIM33, (D) Mustafa Kerem ÇALGIN2, \\ (D) Tevfik NOYAN4
}

1 Ordu University Faculty of Medicine, Department of Physiology, Ordu, Turkey

2 Ordu University Faculty of Medicine, Department of Medical Microbiology, Ordu, Turkey

${ }^{3}$ Ordu University Faculty of Medicine, Department of Infectious Diseases, Ordu, Turkey

${ }^{4}$ Ordu University Faculty of Medicine, Department of Medical Biochemistry, Ordu, Turkey

\begin{abstract}
Objectives: The role of endoplasmic reticulum (ER) stress in the pathogenesis of hepatitis B virus (HBV) has been reported. However, serum levels of glucose-regulated protein (GRP) 78 which is an ER stress marker both in tissue and circulation have not been reported yet. This study aimed to evaluate serum GRP78 levels in patients with chronic HBV infection.

Materials and Methods: A total of 60 patients with HBV infection and 50 control subjects were included in this study. According to HBV-DNA levels, patients with HBV infection were subdivided into low, mild and high HBV-DNA subgroups ( $n=20$, in each). Serum GRP78 level was measured by ELISA and then correlation analysis was performed between GRP78 and alanine aminotransferase (ALT), aspartate aminotransferase (AST), HBV-DNA or hepatitis B surface antigen (HBsAg).

Results: HBsAg levels were significantly higher in each HBV subgroup compared to controls. ALT and AST levels were significantly increased in the high HBV-DNA subgroup. There was no significant difference in serum GRP78 level between controls and HBV subgroups and no correlation between serum GRP78 levels andother variables.

Conclusion: As a result of our study, there was no relationship between the serum level of GRP78 and the HBV infection parameters. Since ER stress is an important mechanism in HBVrelated liver injury, other ER stress markers, such as GRP94, might be examined in future studies.

Keywords: Hepatitis B, glucose-regulated protein 78, endoplasmic reticulum stress
\end{abstract}

$0 ̈ Z$

Amaç: Hepatit B virüsünün (HBV) patogenezinde, endoplazmik retikulum (ER) stresinin rolü daha önceden gösterilmiştir. Ancak, hem dokuda hem de dolaşımda bir ER stres belirteci olan glukozla düzenlenen protein (GRP) 78'in serumdaki seviyesi bugüne kadar çalışımamıştır. Bu çalışmada, kronik HBV enfeksiyonlu hastaların serum GRP78 seviyelerinin değerlendirilmesi amaçlanmıştır.

Gereç ve Yöntemler: Bu çalışma kontrol $(n=50)$ ve HBV $(n=60)$ olmak üzere iki grup ile yapılmıştır. HBV hastaları, HBV-DNA miktarına göre düşük, orta ve yüksek HBV-DNA alt gruplarına (her birinde $n=20$ ) bölünmüştür. Serum GRP78 seviyesi ELISA ile ölçülmüş ve arkasından GRP78 ile alanin aminotransferaz (ALT), aspartat aminotransferaz (AST), HBV-DNA veya hepatit B yüzey antijeni (HBsAg) arasında korelasyon analizi yapıımıştır.

Bulgular: Kontrol ile kıyaslandığında, her bir HBV alt grubunda HBsAg seviyesi önemli yüksek bulunmuştur. ALT ve AST seviyesindeki artış, yüksek HBV-DNA alt grubunda önemli bulunmuştur. Serum GRP78, hem kontrol hem de HBV alt gruplarında benzer düzeylerde olup, serumdaki değişkenlerle bir korelasyon göstermemiştir.

Sonuç: Çalışmamızın sonuçlarına göre, HBV hastalarının parametreleri ile serum GRP78 seviyesi arasında bir ilişki yoktur. ER stresi, HBV ile ilişkili karaciğer hasarında önemli bir mekanizma olduğundan, daha sonraki çalışmalarda GRP94 gibi diğer ER stres belirteçleri incelenebilir.

Anahtar Kelimeler: Hepatit B, glukozla düzenlenen protein78, endoplazmik retikulum stresi

Cırrık S. Çetinkol Y. Altunçekiç Yıldırım A. Çalgın MK. Noyan T. Circulating Glucose-Regulated Protein 78 Levels in Patients with Chronic Hepatitis B Infection. Viral Hepat J. 2018;24:85-89.

Address for Correspondence: Selma Cirrı, PhD, Ordu University Faculty of Medicine, Department of Physiology, Ordu, Turkey Phone: +90 4522265214 E-mail: selmacrrk@yahoo.com ORCID ID: orcid.org/0000-0001-8474-0185 Received: 31.05.2018 Accepted: 31.10.2018

${ }^{\circ}$ Copyright 2018 by Viral Hepatitis Society / Viral Hepatitis Journal published by Galenos Publishing House. 


\section{Introduction}

The endoplasmic reticulum (ER) is a membranous organelle required for folding and processing of nascent proteins. Physiological, pathological or pharmacological insults that disrupt ER function induce accumulation of unfolded or misfolded proteins in the ER lumen. This condition is defined as ER stress and triggers a conserved cellular response called unfolded protein response (UPR) (1). UPR aims to relieve ER stress via different mechanisms, including enhancement of protein folding and degradation processes as well as specific inhibition of protein synthesis in the cell. UPR-related mechanisms are mediated by three different signaling pathways: protein kinase R-like ER kinase (PERK), activated transcription factor 6 (ATF6), and inositolrequiring enzyme 1 (IRE1) (1,2). Although UPR provides a defense mechanism for cells, ER stress can trigger apoptosis depending on the severity and duration of stress $(2,3,4)$. It has been reported that a number of pathophysiological conditions, such as diabetes mellitus, cardiovascular diseases, obesity, cancer, neurodegenerative diseases and hepatic steatosis are associated with excessive or persistent ER stress $(5,6,7,8,9,10)$.

Hepatocytes possess quite well-developed ER and high capacity for protein synthesis similar to other secretory cells. Therefore, ER stress and UPR play an important role in various liver diseases such as non-alcoholic steatohepatitis, alcoholic liver disease, and ischemic reperfusion injury as well as toxic liver damage $(11,12,13,14,15)$. Moreover, different studies conducted on mammalian cells, including hepatocytes, have reported that viruses were also able to induce ER stress. Increased viral protein synthesis in the infected cells induces ER stress by disturbing protein folding mechanisms and enhancing protein aggregates in the ER lumen (16). It is known that hepatitis B virus (HBV) induces ER stress and UPR activation, which contributes to liver pathogenesis during HBV infection $(16,17,18,19)$.

Glucose-regulated protein 78 (GRP78) is an ER resident chaperone protein that monitors ER stress and regulates UPRinduced survival or apoptosis. During ER stress, expression of GRP78 significantly increases; hence, increased expression of GRP78 indicates UPR induction $(1,2,3,4)$. Khadir et al. (20) reported that obesity, which induces hepatic ER stress, caused an elevation in GRP78 levels both in plasma and liver. These results suggest that GRP78 can pass into blood from tissue during hepatic ER stress $(20,21)$. In HBV-infected patients, activation of UPR and its contribution to HBV pathogenesis have been shown previously, however, no circulating marker has been reported. Therefore, alterationsin circulating GRP78 level in patients with chronic HBV infection is evaluated in the present study.

\section{Materials and Methods}

In the current study, samples collected from 60 patients with chronic HBV infection whose serum specimens were processed for HBV-DNA quantification in the molecular microbiology laboratory were evaluated for GRP78 analysis. Control serums were obtained from 50 hepatitis B surface antigen (HBsAg)-, anti-hepatitis C virusand anti-human immunodeficiency virus-negative subjects who had no chronic disease including chronic liver disease. According to HBV-DNA levels, HBV-infected patients were subdivided into low $\left(20-1 \times 10^{2} \mathrm{IU} / \mathrm{mL}, \mathrm{n}=20\right)$, mild $\left(1 \times 10^{3}-1 \times 10^{5} \mathrm{IU} / \mathrm{mL}, \mathrm{n}=20\right)$, and high HBV-DNA $\left(1 \times 10^{6}-1.7 \times 10^{8} \mathrm{IU} / \mathrm{mL}, \mathrm{n}=20\right)$. All the samples were stored at $-40{ }^{\circ} \mathrm{C}$ until assayed throughan ELISA. This study was approved by the Clinical Research Ethics Committee in Ordu University (2017-157).

Real-time polymerase chain reaction: Quantification of HBV-DNA was performed via a real-time polymerase chain reactionmethod using the COBAS AmpliPrep/COBAS Taqman 48 system (Roche, Branchburg, NJ, USA). Viral nucleic acids were extracted from serum $(500 \mu$ l) using Cobas AmpliPrep automatic extractor system according to the manufacturer's instructions. The

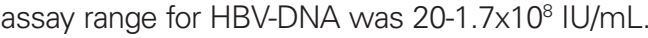

Detection of GRP78: Levels of circulating GRP78 were determined in serum using the human GRP78 ELISA kit (Elabscience; E-EL-H5586) with a detection range of 0.63-40 ng/ $\mathrm{mL}$. Samples and standards were added to the appropriate micro ELISA plate wells pre-coated with an antibody specific to human GRP78 and then the manufacturer's instructions were followed. The optical density was measured spectrophotometrically at the wavelength of $450 \mathrm{~nm}$ (BioTek, ELx800 brand REF ELX508 SN1310149). The level of GRP78 in the samples was calculated by comparing the optical density of the samples with the standard curve.

\section{Statistical Analysis}

All data are given as mean \pm standard deviation. Statistical analysis was performed with One-Way ANOVA and Tukey's test.A $p$ value of less than 0.05 was considered statistically significant.

\section{Results}

Sixty patients with chronic HBV infection $(42.1 \pm 16.0$ years; 28 female, 32 male) and 50 control subjects $(53.9 \pm 19.1 ; 21$ female, 29 male) were included in this study. HBV-DNA content in the

Table 1. Hepatitis B surface antigen, alanine aminotransferaseand aspartate aminotransferaselevels in control ( $n=50$ ) and hepatitis $B$ virus subgroups ( $n=20$, in each subgroup)

\begin{tabular}{|c|c|c|c|c|}
\hline & \multirow[t]{2}{*}{ Control } & \multicolumn{3}{|c|}{ Chronic HBV infection } \\
\hline & & HBV-DNA low & HBV-DNA mild & HBV-DNA high \\
\hline HBsAg (IU/L) & $0.54 \pm 0.07$ & $3668 \pm 3262^{*}$ & $3869 \pm 2397 * \#$ & $2397 \pm 1576 *$ \\
\hline AST (U/L) & $13.50 \pm 4.23$ & 19.1土5.3\#\#\# & $21.4 \pm 5.9 \# \#$ & $59.7 \pm 74.5^{*}$ \\
\hline
\end{tabular}




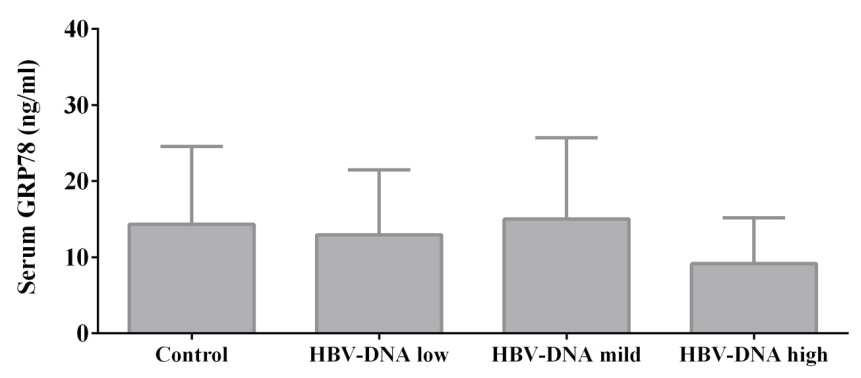

Figure 1. Serum glucose-regulated protein 78 levels in the control and hepatitis $B$ virus subgroups; i.e. hepatitis $B$ virus-DNA low, hepatitis $B$ virus-DNA mild and hepatitis $B$ virus-DNA high HBV: Hepatitis B virus, GRP78: Glucose-regulated protein 78
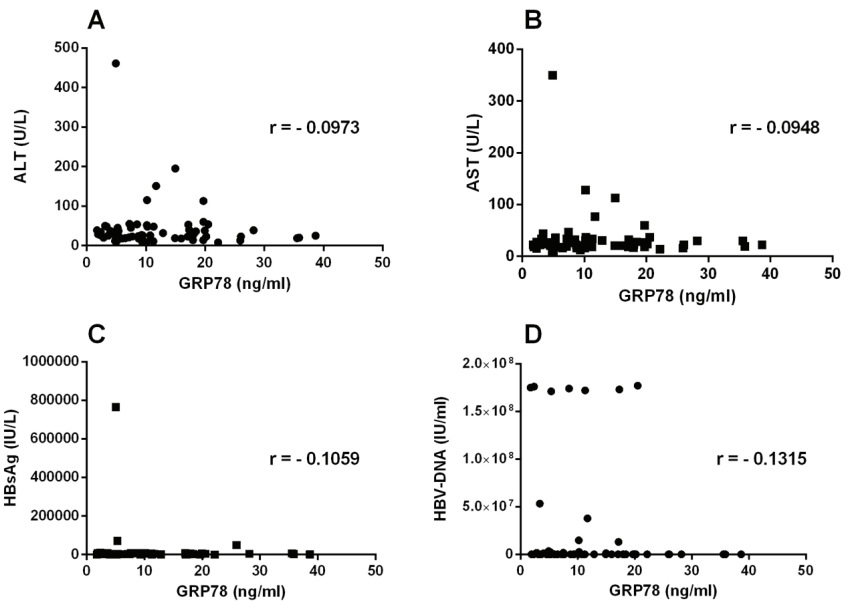

Figure 2. Correlation between serum glucose-regulated protein 78 concentration and serum levels of alanine aminotransferase (A), aspartate aminotransferase (B), hepatitis B surface antigen $(C)$ and hepatitis $B$ virus-DNA (D) in patients with chronic hepatitis $B$ virusinfection. All the patients were included in the correlation analysis $(\mathrm{n}=60)$

HBsAg: Hepatitis B surface antigen, GRP78: Glucose-regulated protein 78, ALT: Alanine aminotransferase, AST: Aspartate aminotransferase, HBV: Hepatitis $B$ virus

serum samples of the patients with chronic HBV infection was in three different ranges of low $\left(20-1 \times 10^{2} \mathrm{IU} / \mathrm{mL}, \mathrm{n}=20\right)$, mild $\left(1 \times 10^{3}-1 \times 10^{5} \mathrm{JU} / \mathrm{mL}, \mathrm{n}=20\right)$, and high $\left(1 \times 10^{6}-1.7 \times 10^{8} \mathrm{IU} / \mathrm{mL}, \mathrm{n}=20\right)$. Serum HBsAg, alanine aminotransferase (ALT) and aspartate aminotransferase (AST) levels in all patients are presented in Table1.

The serum GRP78 concentration was found to be $14.36 \pm 10.22$ $\mathrm{ng} / \mathrm{mL}$ in controls. As seen in Figure1, there was no significant difference in GRP78 concentration between the HBV subgroups $(12.97 \pm 8.5,15.01 \pm 10.7$ and $9.18 \pm 6.02 \mathrm{ng} / \mathrm{mL}$, respectively). In the control group, no correlation was found between GRP78 and serum ALT or AST levels. In each HBV subgroup, changes in serum GRP78 did not show a correlation with the serum variables such as ALT, AST and HBsAg or HBV-DNA content. When all the HBV-infected patients were included in the analysis, we did not determine a correlation between GRP78 and the other variables (Figure2).

\section{Discussion}

Accumulation of unfolded or misfolded proteins in the ER lumen causes a condition termed ER stress $(1,2,3,4)$. During ER stress, UPR is activated to restore cellular homeostasis, however, delayed or insufficient responses to ER stress are implicated with pathological consequences, including fat accumulation, insulin resistance, inflammation, and apoptosis, all of which play important roles in liver pathologies $(11,12,13,14,15)$.

$\mathrm{HBV}$ infection is a serious health problem affecting approximately 260 million people worldwide and causing acute and chronic hepatitis, liver cirrhosis, and even hepatocellular carcinoma (22). To date, many studies have reported on the molecular mechanisms for the relationship between HBV infection and pathogenesis of hepatic diseases, but the mechanisms are still not fully understood (23-25). Recent studies indicate that ER stress may play a role in the pathogenesis of HBV infection $(16,17,18,19)$. It has been reported that some products of HBV genome might be involved in the activation of UPR in hepatocytes. For instance, Li et al. (26) reported that regulatory $X$ protein $(\mathrm{HBX})$, which is a product of $\mathrm{HBV}$ genome, mediated UPR activation in Hep3B and HepG2.2.15 cells via ATF6 and IRE1-XBP1 pathways. Further studies confirmed HBX-induced ER stress in different cell lines $(27,28)$. Additionally, Wang et al. $(29,30)$ reported that the pre-S mutant large HBsAgs were retained in the ER lumen and induced UPR signals, leading to the increased expression of ER chaperones such as GRP78 and GRP94.

In the present study, serum GRP78 levels were evaluated as an ER stress marker in patients with chronic HBV infection whose HBV-DNA levelranged between 80 and $1.7 \times 10^{8} \mathrm{JU} / \mathrm{mL}$. As expected, these patients displayed higher levels of serum HBsAg compared to controls. Since the measurement of serum ALT and AST levels is a common laboratory assay to monitor liver functions, we evaluated these parameters in the subjects. In the control group, the ALT and AST levels were within the normal range. In the HBV subgroups, as the HBV-DNA content raised, serum ALT and AST levels gradually increased. However,a statistically significant elevation was observed only in the HBV subgroup with the highest HBV-DNA content. These results are consistent with the previous reports and suggest that hepatic functions declined during high viral replication $(31,32,33)$.

GRP78 is an ER-resident molecular chaperone which also regulates ER stress and is upregulated during UPR $(1,2,3,4)$. Since HBV induces hepatic ER stress $(16,17,19,26,27,28,29,30)$, we hypothesized that circulating GRP78 increased in HBV-infected patients and then, measured serum GRP78 levels in controls and in patients with chronic HBV infection.Contrary to our expectation, present results showed that during chronic $\mathrm{HBV}$ infection, circulating GRP78 levels remained unchanged without any relationship with serum variables. These results might be attributed to a mechanism that prevents GRP78 release from hepatocytes. Li et al. (26) showed that HBx protein and GRP78 were co-localized in ER lumen and displayed a direct interaction which may results in increased GRP78 retention in ER lumen. The aforementioned HBxGRP78 interaction or another unknown mechanism may prevent GRP78 release to the blood and be responsible for the unchanged serum GRP78 levels in HBV-infected patients. Nevertheless, GRP78 measurements are needed both in liver biopsy and serum samples to confirm this suggestion. 


\section{Study Limitations}

The most important limitations of the current study are small sample size, which included only Turkish subjects, and absence of liver biopsies. It would be valuable data if we had shown the presence of ER stress in liver biopsies obtained from a larger and heterogenous subject population, despite unchanged serum GRP78 concentration.

\section{Conclusion}

Although the involvement of ER stress in HBV-induced liver damage is well-documented, the present results show that serum GRP78 remained unchanged during chronic HBV infection and there was no relationship between serum level of GRP78 and the parameters of HBV infection. Since ER stress is an important mechanism in HBV-related liver injury, other ER stress markers, such as GRP94, might be examined with liver biopsies in future studies conducted with larger patient group.

\section{Ethics}

Ethics Committee Approval: This study was approved by the Clinical Research Ethics Committee in Ordu University (2017-157).

Informed Consent: Retrospective study.

Peer-review: Externally and internally peer-reviewed.

\section{Authorship Contributions}

Concept: S.C., Design: S.C., Y.Ç., Data Collection or Processing: S.C., Y.Ç., M.K.Ç., Analysis or Interpretation: S.C., A.A.Y., T.N., Literature Search: S.C., A.A.Y., Writing: S.C., Y.Ç.

Conflict of Interest: No conflict of interest was declared by the authors.

Financial Disclosure: The authors declared that this study received no financial support. This study was financially supported by Ordu University Research Funds (BAP; HD-1722).

\section{References}

1. Cao SS, Kaufman RJ. Unfolded protein response. Curr Biol. 2012;22:R622-R626.

2. Xu C, Bailly-Maitre B, Reed JC. Endoplasmic reticulum stress: cell life and death decisions. J Clin Invest. 2005;115:2656-2664.

3. Breckenridge DG, Germain M, Mathai JP, Nguyen M, Shore GC Regulation of apoptosis by endoplasmic reticulum pathways. Oncogene. 2003;22:8608-8618.

4. Hiramatsu N, Chiang WC, Kurt TD, Sigurdson CJ, Lin JH. Multiple mechanisms of unfolded protein response-induced cell death. Am J Pathol. 2015;185:1800-1808.

5. Yoshida H. ER stress and diseases. FEBS J. 2007;274:630-658.

6. Remondelli P, Renna M. The endoplasmic reticulum unfolded protein response in neurodegenerative disorders and its potentia therapeutic significance. Front Mol Neurosci. 2017;10:187.

7. Hong J, Kim K, Kim JH, Park Y. The role of endoplasmic reticulum stress in cardiovascular disease and exercise. Int J Vasc Med. 2017;2017:2049217.

8. Lee J, Ozcan U. Unfolded protein response signaling and metabolic diseases. J Biol Chem. 2014;289:1203-1211.

9. Cnop M, Foufelle F, Velloso LA. Endoplasmic reticulum stress, obesity and diabetes. Trends Mol Med. 2012;18:59-68.

10. Schmitz ML, Shaban MS, Albert BV, Gökçen A, Kracht M. The crosstalk of endoplasmic reticulum (ER) stress pathways with
NF-xB: Complex mechanisms relevant for cancer, inflammation and infection. Biomedicines. 2018;6:pii: E58.

11. Ji C, Kaplowitz N. ER stress: can the liver cope? J Hepatol. 2006;45:321-333.

12. Henkel A, Green RM. The unfolded protein response in fatty liver disease. Semin Liver Dis. 2013;33:321-329.

13. Jo H, Choe SS, Shin KC, Jang H, Lee JH, Seong JK, Back SH, Kim JB. Endoplasmic reticulum stress induces hepatic steatosis via increased expression of the hepatic very low-density lipoprotein receptor. Hepatology. 2013;57:1366-1377.

14. Neuman MG, French SW, French BA, Seitz HK, Cohen LB, Mueller S, Osna NA, Kharbanda KK, Seth D, Bautista A, Thompson KJ, McKillop IH, Kirpich IA, McClain CJ, Bataller R, Nanau RM, Voiculescu M, Opris M, Shen H, Tillman B, Li J, Liu H, Thomes PG, Ganesan M, Malnick S. Alcoholic and non-alcoholic steatohepatitis. Exp Mol Pathol. 2014;97:492-510.

15. Rutkowski DT. Liver function and dysfunction - a unique window into the physiological reach of ER stress and the unfolded protein response. FEBS J. 2018.

16. Yeganeh B, Rezaei Moghadam A, Alizadeh J, Wiechec E, Alavian SM, Hashemi M, Geramizadeh B, Samali A, Bagheri Lankarani K, Post M, Peymani P, Coombs KM, Ghavami S. Hepatitis B and $C$ virus-induced hepatitis: Apoptosis, autophagy, and unfolded protein response. World J Gastroenterol. 2015;21:13225-13239.

17. Kim SY, Kyaw YY, Cheong J. Functional interaction of endoplasmic reticulum stress and hepatitis $B$ virus in the pathogenesis of liver diseases. World J Gastroenterol. 2017;23:7657-7665.

18. Chen BF. Hepatitis B virus pre-S/S variants in liver diseases. World J Gastroenterol. 2018;24:1507-1520.

19. Li YW, Yang FC, Lu HQ, Zhang JS. Hepatocellular carcinoma and hepatitis B surface protein. World J Gastroenterol. 2016;22:194352.

20. Khadir A, Kavalakatt S, Abubaker J, Cherian P, Madhu D, Al-Khairi I, Abu-Farha M, Warsame S, Elkum N, Dehbi M, Tiss A. Physical exercise alleviates ER stress in obese humans through reduction in the expression and release of GRP78 chaperone. Metabolism. 2016;65:1409-1420.

21. Delpino A, Castelli $\mathrm{M}$. The $78 \mathrm{kDa}$ glucose-regulated protein (GRP78/BIP) is expressed on the cell membrane, is released into cell culture medium and is also present in human peripheral circulation. Biosci Rep. 2002;22:407-20.

22. World Health Organization, Global Hepatitis Report 2017. Available at: http://www.who.int/hepatitis/publications/global-hepatitisreport2017/en/

23. Levrero $M$, Subic $M$, Villeret $F$, Zoulim F. Perspectives and limitations for nucleo(t)side analogs in future HBV therapies. Curr Opin Virol. 2018;30:80-89.

24. Inan N, Tabak F. Hepatitis B virus: Biology and life cycle. Viral Hepat J. 2015;21:1-7.

25. Tang LSY, Covert E, Wilson E, Kottilil S. Chronic hepatitis B infection: A review. JAMA. 2018;319:1802-1813.

26. Li J, He J, Fu Y, Hu X, Sun LQ, Huang Y, Fan X. Hepatitis B virus $X$ protein inhibits apoptosis by modulating endoplasmic reticulum stress response. Oncotarget. 2017;8:96027-96034.

27. Cho HK, Kim SY, Kyaw YY, Win AA, Koo SH, Kim HH, Cheong J. $\mathrm{HBx}$ induces the proliferation of hepatocellular carcinoma cells via AP1 over-expressed as a result of ER stress. Biochem J. 2015;466:115-121.

28. Cho HK, Cheong KJ, Kim HY, Cheong J. Endoplasmic reticulum stress induced by hepatitis $B$ virus $X$ protein enhances cyclooxygenase 2 expression via activating transcription factor 4 . Biochem J. 2011;435:431-439.

29. Wang HC, Wu HC, Chen CF, Fausto N, Lei HY, Su IJ. Different types of ground glass hepatocytes in chronic hepatitis $B$ virus infection 
contain specific pre-S mutants that may induce endoplasmic reticulum stress. Am J Pathol. 2003;163:2441-2449.

30. Wang HC, Huang W, Lai MD, Su IJ. Hepatitis B virus pre-S mutants, endoplasmic reticulum stress and hepatocarcinogenesis. Cancer Sci. 2006;97:683-688.

31. Köse $S$, Gülcü FO, Topaloğlu S, lyi T. The association between Hepatit B virus (HBV) DNA levels, alanin aminotransferaz levels and HBV serologic markers. Viral Hepat J. 2011;17:57-61.
32. Külah C, Cömert F, Özlü N, Eroglu Ö, Tekin IÖ. Evaluation of serological markers, transaminase levels and HBV DNA in hepatitis B virus infections. Viral Hepat J. 2007;12:111-115.

33. Tülin Demir T, Koçdemir E, Milletli Sezgin F. The association between hepatitis B virus (HBV)-DNA levels and biochemical markers. Viral Hepat J. 2014;20:4-7. 